\title{
REFLECTIONS ON THE EVOLUTION OF THE CEREALS' MARKET IN ROMANIA
}

\section{Dan Marius Voicilas ${ }^{1}$}

\begin{abstract}
The objectives of the paper are to provide a picture with the main characteristics and the dynamics of the cereals' market from Romania in the last decades, before and after Romanian EU accession. This image and the personal comments are presented in the direct connection with the actual context of high level of competitiveness at regional level, EU level and international level. Generally, the cereals' market has had a dynamic evolution at international level, also regional level. Romania is part of the Black Sea Region, also EU member, two important cereals players in the world. Romania has the major Eastern port of the EU on the Black Sea coast, Constanta, which is the main door for EU cereal trade to East. This is the reasons why we analyse the evolution of the cereals' market from Romania before and after EU accession and we want to emphasize the transformations of the Romanian market during this period. The applied methodology contains a statistical analysis based on areas, yields and production indicators, also the trade flows. It is analysed long series of data provided by the Romanian National Institute of Statistics, Romanian Ministry of Agriculture and Rural Development, also FAO and Eurostat where they were useful. Besides these, we use results of qualitative analysis based on interviews and opinion of experts in the field, information, declarations and comments published in press, by officials from administration or business.
\end{abstract}

The results of the analysis emphasis the present state of the Romanian market, the evolution in the last decades, also the main constraints for a better evolution of the cereals' market in Romania, the improvements and the main challenges for the future.

Key words: Cereals, Market characteristics, Pre-accession period, EU membership, Romania.

JEL'2: Q13, Q17

1 Dan Marius Voicilas, Ph.D., Associate Professor, CS II, Romanian Academy, Institute of Agricultural Economics (IAE), Calea 13 Septembrie no. 13, sector 5, 050711 Bucharest, Romania, Phone: +40 722398 119, E-mail: dmvoici@yahoo.com

2 Article info: Original Article, Received: 20 $0^{\text {th }}$ June 2020, Accepted: $16^{\text {th }}$ July 2020. 


\section{Introduction}

European geopolitical changes in recent decades have directly influenced international trade and agri-food markets. International trade agreements and regulations developed at European Union (EU) level for agri-food markets have introduced new rules for the actors involved. This was also the case for the cereal's markets. In recent years, the international cereals' market has evolved dynamically. The analyse is realised because there are new trends in the field, which are the results of the new and complex international and regional context, which includes the high level of competitiveness from different major actors in the world like EU countries, the Black Sea countries, North American countries, and South American countries. Because Romania is part of the Black Sea Region the article analyses the Romanian market and its dynamics. The Black Sea Region covers a huge area and it is an active player on the European and international market for agri-food products (see Figure 1). In its area, there are countries with huge agricultural potential for grain production, good soils and good facilities for international trade, due to the presence of important ports along the Black Sea coast and the Danube River, among other ports on important rivers in former Commonwealth of Independent States (CIS).

Figure 1. Black Sea Basin

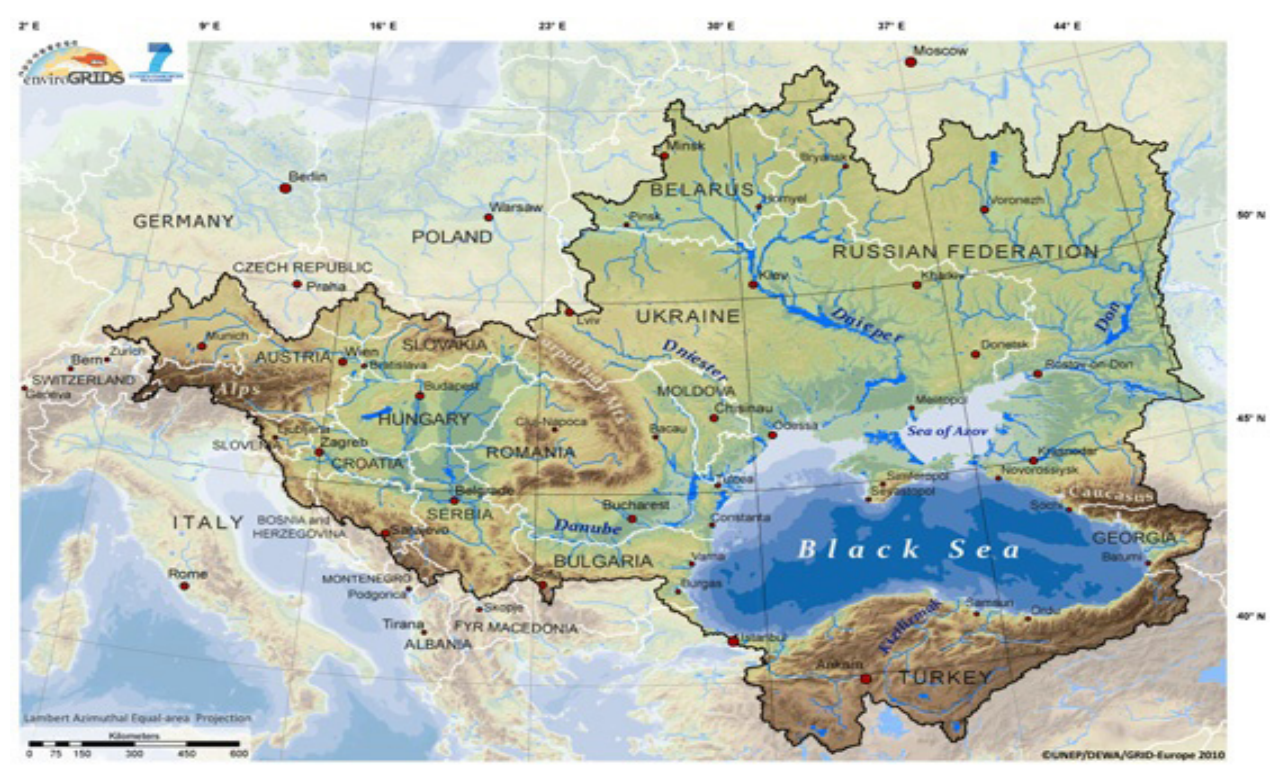

Source: after EnviroGRIDS, 2012.

The current situation of the cereals' market in the region reflects the effects of EU enlargement and trade globalization, as well as the influences that have emerged as a result of the high level of competitiveness in other countries around the world. 
Black Sea Region has developed and continues to develop in the global context of economic development. Romanian market followed the trend. In the same time, the demand for cereals has increased. Overall, wheat consumption is expected to increase in the next decade. It is estimated that, the use of wheat feed will increase in general, but especially in countries with large populations and high demand for bakery and meat products such as China, Pakistan and Vietnam. The share of the top 5 wheat importers (Egypt, Indonesia, Algeria, Brazil, and Japan) is likely to remain consistently high. Intensification of world maize consumption is also planned. Namely, the consumption of maize per capita will increase, especially in Africa. Also, it is expected that, Vietnam will join the above-mentioned group of states and has a chance to replace Egypt as the $5^{\text {th }}$ largest importer of maize.

Obviously, the increase in consumption and demand for grain in the world is due to economic development and changing in consumer preferences, but first and foremost it is the result of increasing world population. The population growth will occur mainly in Africa and Asia, continents that still have large populations. This is the current picture of international markets and the development prospects of the cereals market, which leads us to believe that this market will have a dynamic upward evolution in the future.

\section{Literature Review}

The cereals market has often been analysed by various authors both in Romania and in the world. As it is an important sector of crop production, we consider it useful to deepen this topic. We want to analyse the grain market from another perspective and for this we conduct the analysis performed from the previous works of the author, namely "Gains and losses of Romanian agri-food products on EU intra-trade market" (Voicilaş, 2013), "Cereal market in Romania-regional competitiveness" (Voicilaş, 2014), "Competitiveness of the Romanian agri-food trade and the new agricultural policies" (Gavrilescu, Voicilaş, 2014). Previous research by other Romanian authors has also been used, such as "The Romanian cereal production at regional level" (Sima, 2009). The publications of the Romanian National Institute of Statistics and the reports of some international institutions facilitated the realization of the written article, such as "Territorial competitiveness - Creating a territorial development strategy in light of the LEADER experience" (EC, 1999).

\section{Methodology and Used Data Sources}

The applied methodology contains an analysis of statistical data, namely areas, productions, yields, and trade flows indicators. The analysis covers the period 2000- 
2006, until Romanian EU accession and then, the period as EU member, since 2007. Long series of data provided by the Romanian National Institute of Statistics (INS), the Romanian Ministry of Agriculture and Rural Development (MADR) and FAO data were analysed. We also completed the article using the results of qualitative analyses based on interviews and the opinion of experts in the field. In addition, we used information, statements and comments published in press by officials or business leaders.

\section{Results and Discussion}

Areas, productions and yields

Agriculture is a branch with old traditions in the Romanian economy, which in recent years has contributed about 5\% to the formation of Gross Domestic Product (GDP), according to data published by INS (Pana, 2019). In agriculture, plant culture is predominant (animal husbandry has declined in the last three decades). In turn, crop production is concentrated on two major crops: cereals and oilseeds. Cereals represent the main crop practiced on arable land, on average $67.8 \%$ of the arable land (Sima, 2009) and this is a consequence of tradition, aside, but also of favourable fertile soil conditions in the south, southwest and southeast of the country. Among cereals, wheat and corn are the main crops, but are grown in smaller quantities barley, rye or oats, as well. Therefore, it can be said that Romania's agriculture has a cereal character which is determined both by the need for self-sufficiency of the population's consumption, and by the favourable environmental conditions (Sima, 2009) and by the export opportunities as an EU member country.

The INS and MADR statistical data are in support of the above. We will divide the analysis of the main indicators into two periods, the one before the accession into the EU and the one after the EU accession. Thus, before EU accession, the evolution of the main Romanian indicators, i.e. cultivated areas, average productions and total productions, for cereals cultivated in Romania is presented in Table 1.

During the analysed period, at least 5.5 million ha (2003) were cultivated with cereals (MADR, 2020), which demonstrate the specialization on cereals of Romanian agriculture. Among cereals, the areas cultivated with corn were predominant (at least $44.8 \%$ of the surface cultivated with cereals in Romania in 2005), then those with wheat, with at least $31.3 \%$ in 2003 . These weights show that corn and wheat are the main cereals grown in Romania, together accounting for between $85.9-89 \%$ of the area cultivated with cereals.

Regarding the average productions obtained, we notice that they fluctuated from year to year, for all cereals. The lowest averages were in 2003 for wheat, rye and barley 
and in 2000 for maize. 2002 was also an agricultural year with poor yields, especially for corn and rye. Only in one situation (2004) did the yields approach those of the western EU countries, both for wheat and maize.

Overall, variations in total cereal production were very large, from 10,477.5 thousand tons in 2000 to $24,403.0$ thousand tons in 2004 (2.3 times higher). The largest variations were for wheat 3.1 times (2004 compared to 2003), for rye 3.1 times in the same period, for barley 2.9 times (2001 compared to 2003) and 2.9 times for corn (2004 compared to 2000). It follows that the weakest year was 2003, and the best 2004. It is obvious that the variations were mainly determined by climatic conditions, by the lack of precipitation and the lack of irrigation system necessary to replace it, but also by the inappropriate use of modern fertilizers and technologies.

Table 1. Cereal indicators in Romania (EU pre-accession period)

\begin{tabular}{|c|c|c|c|c|c|c|c|c|}
\hline Parameter & Crop & 2000. & 2001. & 2002. & 2003. & 2004. & 2005. & 2006. \\
\hline \multirow{5}{*}{$\begin{array}{l}\text { Area } \\
(000 \text { ha })\end{array}$} & Wheat & 1,940 & 2,546 & 2,297 & 1,735 & 2,296 & 2,476 & 2,013 \\
\hline & Rye & 14 & 12 & 12 & 13 & 22 & 21 & 17 \\
\hline & Barley & 412 & 529 & 579 & 330 & 425 & 485 & 332 \\
\hline & Corn & 3,049 & 2,974 & 2,895 & 3,200 & 3,274 & 2,628 & 2,520 \\
\hline & Total & 5,655 & 6,295 & 6,038 & 5,542 & 6,265 & 5,866 & 5,114 \\
\hline \multirow{4}{*}{$\begin{array}{l}\text { Yields (kg/ } \\
\text { ha) }\end{array}$} & Wheat & 2,286 & 3,038 & 1,924 & 1,429 & 3,403 & 2,965 & 2,746 \\
\hline & Rye & 1,549 & 2,326 & 1,636 & 1,356 & 2,511 & 2,371 & 2,072 \\
\hline & Barley & 2,105 & 2,988 & 2,005 & 1,641 & 3,312 & 2,227 & 2,331 \\
\hline & Corn & 1,603 & 3,066 & 2,902 & 2,993 & 4,441 & 3,952 & 3,565 \\
\hline \multirow{5}{*}{$\begin{array}{l}\text { Total } \\
\text { production } \\
(000 \mathrm{t})\end{array}$} & Wheat & $4,434.4$ & $7,735.1$ & $4,421.0$ & $2,479.1$ & $7,812.4$ & $7,340.7$ & $5,526.2$ \\
\hline & Rye & 21.8 & 28.6 & 20.1 & 17.4 & 55.0 & 49.0 & 35.7 \\
\hline & Barley & 867.0 & $1,580.0$ & $1,160.4$ & 540.8 & $1,406.0$ & $1,079.1$ & 772.9 \\
\hline & Corn & $4,897.6$ & $9,119.2$ & $8,399.8$ & $9,577.0$ & $14,541.6$ & $10,388.5$ & $8,984.7$ \\
\hline & Total & $10,477.5$ & $18,870.9$ & $14,356.5$ & $12,790.3$ & $24,403.0$ & $19,345.5$ & $15,759.3$ \\
\hline
\end{tabular}

Source: Sima, 2009; MADR, 2020.

After Romania joined EU, the situation of cereals in Romania did not change radically, but it has been improved compared to the pre-accession period. Regarding the indicators considered for analysis, the cultivated areas were dominated by corn and wheat (between 4-5 million ha annually), had a constant general dynamic, and corn was preferred over wheat, as before.

The average yields continued to fluctuate, but they did not have the amplitude of the previous period. As a general trend for the period 2007-2015, the evolution of yields was upward, except for 2012 when they were the weakest of the whole period, as a result of unfavourable climatic conditions and lack of irrigation systems. 
As a result of the two previous indicators, the total production evolved in general increasing, with those variations caused by the dry years (2012), or the corresponding non-use of fertilizers, especially at the beginning of the period. Improvements in cereal crops in the post-accession period are evident, which highlights an increase in economic performance and competitiveness of the sector. This growing competitiveness must be analysed in comparison with the previous period, not with the results obtained by other EU member states, especially France, Germany or the Netherlands, the main Community countries competing for Romania. The main indicators of the analysed post-accession period are presented in Table 2.

Table 2. Cereal indicators in Romania (period after EU accession)

\begin{tabular}{|l|c|c|c|c|c|c|c|c|c|}
\hline Wheat & $\mathbf{2 0 0 7}$ & $\mathbf{2 0 0 8}$ & $\mathbf{2 0 0 9}$ & $\mathbf{2 0 1 0}$ & $\mathbf{2 0 1 1}$ & $\mathbf{2 0 1 2}$ & $\mathbf{2 0 1 3}$ & $\mathbf{2 0 1 4}$ & $\mathbf{2 0 1 5}$ \\
\hline Surface $(000 \mathrm{ha})$ & 1,975 & $2,110.3$ & $2,148.8$ & $2,162.4$ & 1,947 & $1,997.6$ & 2,104 & $2,112.9$ & 2,043 \\
\hline Yield $(\mathrm{kg} / \mathrm{ha})$ & 1,541 & 3,403 & 2,421 & 2,688 & 3,663 & 2,652 & 3,468 & 3,590 & 3,842 \\
\hline Total $(000 \mathrm{t})$ & $3,044.5$ & 7,181 & $5,202.5$ & $5,811.8$ & $7,131.6$ & $5,297.7$ & $7,296.4$ & $7,584.8$ & 7,851 \\
\hline Corn & $\mathbf{2 0 0 7}$ & $\mathbf{2 0 0 8}$ & $\mathbf{2 0 0 9}$ & $\mathbf{2 0 1 0}$ & $\mathbf{2 0 1 1}$ & $\mathbf{2 0 1 2}$ & $\mathbf{2 0 1 3}$ & $\mathbf{2 0 1 4}$ & $\mathbf{2 0 1 5}$ \\
\hline Surface $(000 \mathrm{ha})$ & $2,524.7$ & $2,441.5$ & $2,338.8$ & $2,098.4$ & $2,589.7$ & $2,730.2$ & $2,518.3$ & $2,512.8$ & 2,528 \\
\hline Yield $(\mathrm{kg} / \mathrm{ha})$ & 526 & 3,215 & 3,409 & 4,309 & 4525 & 2,180 & 4,488 & 4,770 & 3,509 \\
\hline Total $(000 \mathrm{t})$ & 853.9 & $7,849.1$ & $7,973.3$ & 9,042 & $11,717.6$ & $5,953.4$ & $11,305.1$ & $11,988.6$ & 8,871 \\
\hline Barley & $\mathbf{2 0 0 7}$ & $\mathbf{2 0 0 8}$ & $\mathbf{2 0 0 9}$ & $\mathbf{2 0 1 0}$ & $\mathbf{2 0 1 1}$ & $\mathbf{2 0 1 2}$ & $\mathbf{2 0 1 3}$ & $\mathbf{2 0 1 4}$ & $\mathbf{2 0 1 5}$ \\
\hline Surface $(000 \mathrm{ha})$ & 363.8 & 394 & 517.5 & 515.8 & 419.5 & 424.2 & 495.7 & 516 & 462 \\
\hline Yield $(\mathrm{kg} /$ ha) & 1,461 & 3,069 & 2,284 & 2,542 & 3,170 & 2,325 & $3,250,5$ & 3,319 & 3,424 \\
\hline Total $(000$ t) & 531.4 & $1,209.4$ & $1,182.1$ & 1,311 & $1,329.7$ & 986.4 & $1,542.2$ & $1,712.5$ & 1,582 \\
\hline
\end{tabular}

Source: processing after Cristu et al., 2016.

\section{Trade}

With regard to trade in cereals, we analyse both exports and imports, at intraCommunity and extra-Community level, for both periods considered.

The period 2000-2006 is characterized by reduced trade flows, both at intracommunity and extra-community level (Figure 2.). The trade balance was both positive and negative, but in terms of value and quantity trade was reduced. Romania was unconnected to international trade flows. After 2007, EU membership brought many advantages, including access to the European single market, but also the possibility of increasing extra-EU exports as a beneficiary of EU trade agreements. Since 2008, trade with non-EU countries has been steadily positive and growing. The same happened with the total balance of Romania's grain trade. In comparison, the balance of intra-Community trade was also positive, but lower in value and quantity than the extra-Community one. 
Figure 2. Total balance of cereals trade (in 000 EUR)

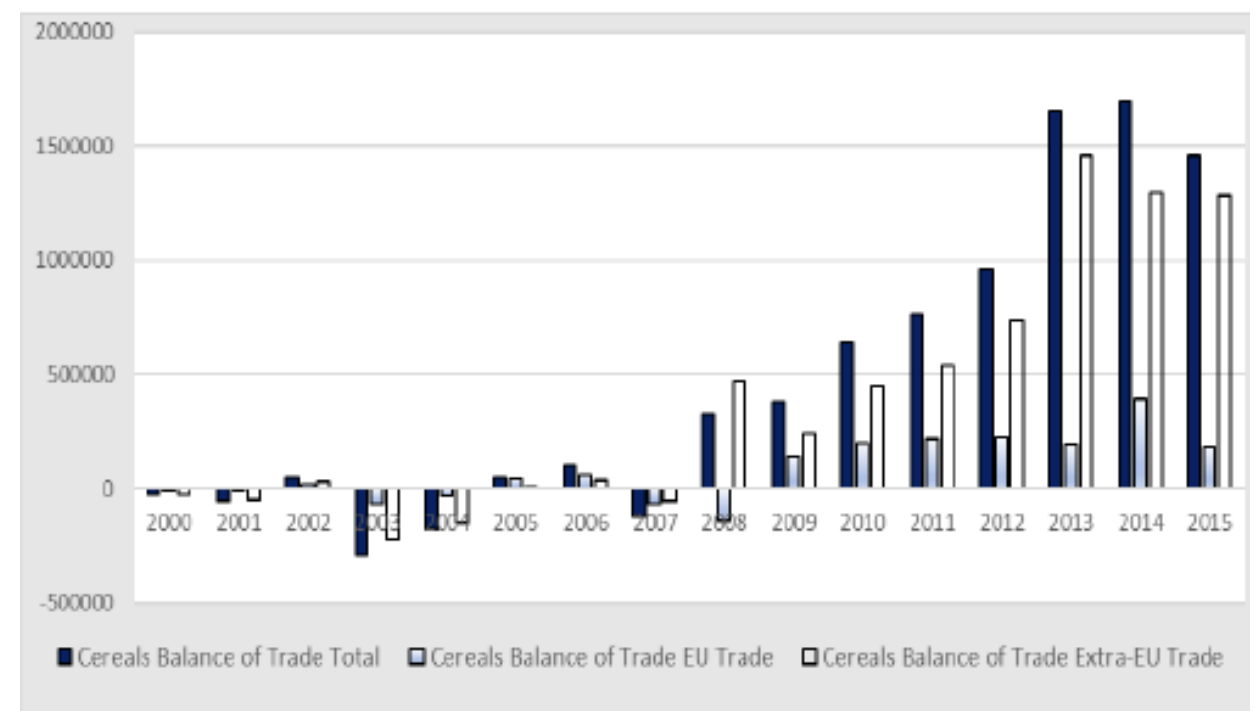

Source: Gavrilescu, Voicilaş, 2014.

When we analyse separately the intra-community trade with cereals, the situation is presented as in Figure 3.

Figure 3. Intra-EU Cereals Trade (in \%)

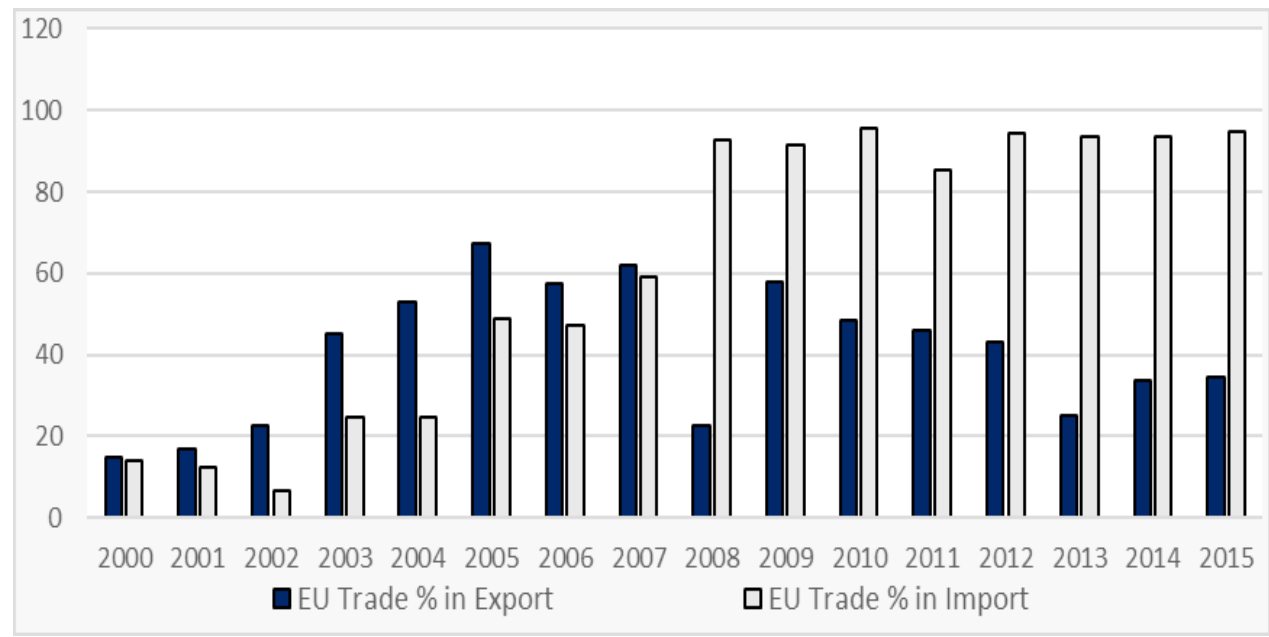

Source: INS, 2020.

The share of intra-Community trade of cereals in total exports, as well as in the case of imports, was permanently positive. The share of total exports in the period 2000-2006 is characterized by significant increases, and the period 2007-2015 is characterized 
by a continuous decrease, due to the pressure of products from the EU market, products with a high degree of quality and competitiveness. In comparison, the share of intra-Community trade of cereals in total cereal imports had a permanent increase in both periods analysed. A rapid jump is observed in 2008, compared to 2007, when Romania was member of the EU, and the intra-community market mechanisms were already working in Romania. In fact, 2008 is characterized as a weak year in terms of the share of exports in intra-Community trade, during which time EU products had easy access to the Romanian market due to the lack of strong competition from domestic producers. Since that year, the share of total imports has remained high, but relatively constant for the analysed period. This show that immediately after accession, Romania could not cope with intra-community competitiveness and the impact was strong. It also shows that Romania's main partner in the case of imports is the EU (over $90 \%$ of total grain imports). Regarding exports, the intra-community market is less accessible to Romanian products, a fact reflected in their lower share (not more than $40 \%$ of total exports) compared to the share of imports, which shows, again, the lack of competitiveness of products from Romania.

With regard to extra-Community trade in cereals, the situation is different from intraCommunity trade, as shown in Figure 4.

Figure 4. Extra-EU Cereals Trade (in \%)

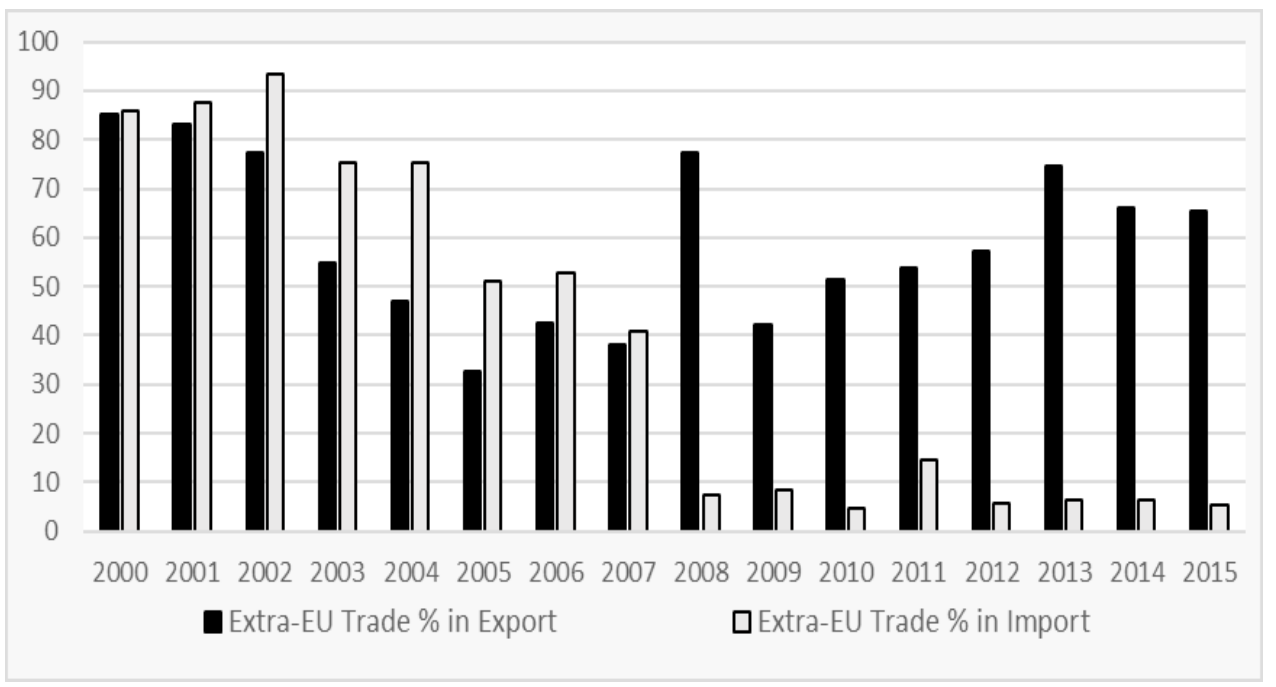

Source: INS, 2020.

The share in the extra-community trade in cereals in total exports, as well as the share in total imports, was permanently positive, as in the case of intra-Community trade. But the evolution was different. Thus, the share of extra-Community exports 
in total cereal exports was decreasing in the period 2000-2006, and then fluctuated in the post-accession period. On the other hand, the share of extra-Community imports in total grain imports gradually decreased in the period 2000-2006, so that from 2008 to be at a low level, constantly. This is clear evidence of the growing role that non-EU countries play since accession, as the main partner in the grain trade, in terms of exports made by Romania and the decrease in trade flows with them in the case of imports. We remind that in the case of grain imports, Romania's main partner is the EU.

\section{Key determinants for the evolution of the cereal market}

At the end, we want to mention a series of factors that were identified as having negative influences on the evolution of cereals in Romania, especially in the preaccession period.

Dualism and polarization of agricultural structures had negative influences on cultivated areas, yields and total production. Distribution of agricultural holdings has a strong double character. Average agricultural area of a farm in Romania is well below the average size of an EU farm. About $80 \%$ of the utilized agricultural area is divided between two categories: $80 \%$ of total holdings consist small holdings under 5 ha and the rest consist holdings with over 50 ha, as shown by INS data (INS, 2020). The intermediate segment is poorly represented, but this segment deserves to be developed in order to maintain a certain balance between producers and their supply on the domestic market. This can be done by turning some of the small ones into medium-sized producers, either through special government programs or by accessing EU funds by small ones who want to develop.

Unused (abandoned) land is alarming phenomenon's that could be and can be still observed in Romanian agriculture, and here we do not include only the land legally removed from the agriculture due to the development of localities, industrial platforms and service spaces. We also consider the land, which is legally unused, in accordance with EU regulations (for regeneration). The third category of land we talk about is the land unused after their abandonment by the owners. All these categories have negative effects on the performance of the Romanian agriculture.

The competitiveness of cereals in the Black Sea Basin has been for many years a factor of pressure on the Romanian market, due to fierce competition from similar products from the main competitors in the Black Sea Region, and here we include Ukraine, Russia, and Kazakhstan.

Another factor that negatively influenced the Romanian grain market for many years was the "blackmarket", precisely the tax evasion. Romanian officials (Financial Guard, 
ANAF, Competition Council) have often admitted that there is a "black market" for cereals (Burlacu, 2002; Anton, 2006; Popescu, 2009; Trif, 2010), but official figures indicating the size of this market do not exist only as estimates. According to some specialists, the "black market" of transactions with cereals, mainly wheat, represented in the past about half of the Romanian market. For example, a preliminary report by the Competition Council in early 2009 showed that, illicit wheat sales in Romania represent $40 \%$ of total transactions (report on the investigation useful for knowing the bakery grain market, triggered by the Order of the President of the Competition Council), (Consiliul Concurenței, 2009).

Pressure on the price of agricultural land is another factor to consider. This pressure is affecting grain business, whether it is an increase as a result of real estate speculation, whether it is a strategic investment or whether it is a normal increase in prices due to the transition from the status of candidate country to accession to EU member state status.

\section{Conclusion}

The results show that, in the last decades the cereals' market in Romania had positive developments underlined by the size of areas, yields, total production, and trade. This development favoured mostly exports. At the same time, there were factors that slowed down the evolution of the analysed indicators. Thus, a problem that the authorities must solve is the lack of adequate infrastructure and logistics to the potential. We have in view the lack of storage facilities, even if their construction process has accelerated in recent years, or the lack of transport infrastructure to the main ports through which products are exported, i.e. the port of Constanta from the Black Sea coast or other ports from the Danube River. Also, a common problem identified is the lack of functional irrigation systems, to make up for the lack of precipitation in certain years, or certain periods of the year, or finding solutions so that Romania no longer export premium without added value and to import finished products with added value, which affects the trade balance. The price of oil, as well as the refugee crisis can affect to some extent, indirectly, the analysed sector and especially the international trade. In this general context, we must not omit the increasingly perceptible climate change in recent years, but also the legislation, policies and strategies adopted by the governments and which have encouraged the development of bipolar agriculture.

On the other hand, factors with a positive effect on the cereal sector were identified. Here we include the EU accession, which forced the increase of the competitiveness of agri-food products, even if for the short and medium term it had a negative impact on the trade balance, precisely due to the lack of competitiveness of the Romanian products. 
In recent years, the Black Sea Region has become the second largest grain market in Europe, as the official data from Eurostat show (Eurostat, 2020). It is clear that, for Romania the competitors in the Black Sea Region are Ukraine, Russia and Kazakhstan (FAO Data and reports, FAO, 2020), as the result of their surfaces cultivated with cereals and productions obtained. It is a permanent competition that takes place not only in terms of production and yields obtained, but also in terms of trade that takes place through the main ports on the Black Sea.

In a few words, we conclude as follows: Romanian market is less developed in EU; at the same time is one of the most competitive Romanian sectors, compared to other sectors at national level. It is clear that for many years, the lack of stable and rigorous legislation and the weaknesses of national institutions have led to market uncertainty and underperformance, a market that cannot compete with other EU or world markets such as the EU, US and Canada. The problems analysed in this paper are not exhausted, but they represent the main characteristics of the evolution of the Romanian cereals market in the last decades.

\section{References}

1. Anton, C. (2006). 40 de miliarde de lei, confiscate de pe piata neagra a cerealelor. Portal HotNews, Bucharest, Romania, retrieved at: www.hotnews.ro/ stiri-presa regionala arhiva-1723847-ultima-mare-lovitura-garzii-40-miliardelei-confiscate-piata-neagra-cerealelor.htm, $2^{\text {nd }}$ June 2020.

2. Burlacu, G. (2002). Piata neagra a cerealelor prospera din intermedieri ilegale. Portal Curentul International, Romania, retrieved at: www.curentul.info/ economic-financiar/piata-neagra-a-cerealelor-prospera-din-intermedieri-ilegale/, $1^{\text {st June } 2020 .}$

3. Consiliul Concurenței (2009). Raport privind investigația utilă pentru cunoaşterea pieței cerealelor de panificație, declanşată prin Ordinul Preşedintelui Consiliului Concurenței $n r$. 264/06.09.2007, retrieved at: www.consiliulconcurentei.ro/wpcontent/uploads/2020/01/Raport investigatie utila pentru_cunoasterea pietei cerealelor de panificatie final-1.pdf, $2^{\text {nd }}$ June 2020.

4. Cristu, C., Scurtu Cristu, M., Stanciu, S. (2016). An analysis of the evolution of Romania's cereals production and trade in the period of post-accession to the EU community economic space. In: Soliman, K. S. (Edt.) $28^{\text {th }}$ IBIMA Conference, Proceedings, Seville, Spain, pp. 1501-1514. 
5. EC (1999). Territorial competitiveness: Creating a territorial development strategy in light of the LEADER experience. Rural Innovation Dossier no. 6, LEADER European Observatory, European Commission (EC), Brussels, Belgium, retrieved at: http://ec.europa.eu/agriculture/rur/leader2/rural-en/biblio/ compet/intro.htm, 25 ${ }^{\text {th }}$ May 2020.

6. EnviroGRIDS (2012). The Black Sea Catchment. Webpage of the project EnviroGRIDS, EU, Brussels, Belgium, retrieved at: www.envirogrids.net/ indexab45.html?option $=$ com content $\& v i e w=$ article $\& i d=5 \&$ Itemid $=16$, $5^{\text {th }}$ June 2020.

7. Eurostat (2020). Cereals market. Database of the Eurostat, Luxemburg, retrieved at: http://epp.eurostat.ec.europa.eu/, $4^{\text {th }}$ June 2020.

8. FAO (2020). Cereal market. Database of the Food and Agriculture Organization of the UN (FAO), Rome, Italy, retrieved at: www.fao.org/home/en/, $4^{\text {th }}$ June 2020.

9. Gavrilescu, C., Voicilaş, D. M. (2014). Competitiveness of the Romanian agrifood trade and the new agricultural policies. In: Kowalski, A., Wigier, M., Bulkovska, M. (Eds.) The new EU agricultural policy: Continuation or revolution?, Institute of Agricultural and Food Economics, Warsaw, Poland, no. 99/1:95-106.

10. INS (2020). Cereals trade. Database of the Romanian National Institute of Statistics (INS), Bucharest, Romania, retrieved at: www.insse.ro, $7^{\text {th }}$ June 2020.

11. MADR (2020). Cereals production. Database of the Romanian Ministry of Agriculture and Rural Development (MADR), Bucharest, Romania, retrieved at: www.madr.ro/culturi-de-camp/cereale.html, $6^{\text {th }}$ June 2020.

12.Pana, M. (2019). Bilanțul Agriculturii 2018 - contribuția la PIB. Portal Curs De Guvernare, Scădere generalizată în zootehnie, creșteri la vegetale în Vest. Retrieved at: https://cursdeguvernare.ro/bilantul-agriculturii-2018contributia-la-pib-scadere-generalizata-in-zootehnie-cresteri-la-vegetale-invest.html, $11^{\text {th }}$ July, 2020.

13. Popescu, A. (2009). Piaţa neagră a grâului de contraband. Portal EVZ, Bucharest, Romania, retrieved at: https://evz.ro/piata-neagra-a-graului-decontrabanda-857525.html, ${ }^{\text {st }}$ June 2020.

14. Sima, E. (2009). The Romanian cereal production at regional level. Agricultural Economics and Rural Development, New Series, 6(1):91-102.

15. Trif, C. (2010). Piața neagră a cerealelor pune capac hambarelor româneşti. Portal Revista Ferma, Timisoara, Romania, retrieved at: www.revista-ferma. ro/articole/afaceri-agricole/piata-neagra-a-cerealelor-pune-capac-hambarelorromanesti, $2^{\text {nd }}$ June 2020. 
16. Voicilas, D. M. (2013). Gains and losses of Romanian agri-food products on EU intra-trade market. In: Popescu, G., Istudor, N., Boboc, D. (Eds.), $2^{\text {nd }}$ International Conference Competitiveness of agro-food and environmental economy (CAFEE'13), ASE, Bucharest, Romania, pp. 401-409, retrieved at: www.cafee.ase.ro/?page id=202, $11^{\text {th }}$ June 2020.

17. Voicilas, D. M. (2014). Cereal market in Romania-regional competitiveness. In: Turek, A. (Edt.) $5^{\text {th }}$ International Conference Agrarian economy and rural development: Realities and perspectives for Romania, ICEADR, Bucharest, Romania, pp. 94-103, retrieved at: www.econstor.eu/bitstream/10419/111616/1/ ICEADR-2014 p094.pdf, $4^{\text {th }}$ June 2020. 